\title{
Glutathione S-Transferase Activity in Tissues of Rats Exposed to Fenarimol
}

\author{
Halime Ozcelebi ${ }^{1}$ \\ https://orcid.org/0000-0002-2048-3252 \\ Ferda Ari ${ }^{1 \star}$ \\ https://orcid.org/0000-0002-6729-7908
}

\section{Egemen Dere ${ }^{1}$}

https://orcid.org/0000-0001-9572-1051

${ }^{1}$ Bursa Uludag University, Faculty of Art and Science, Department of Biology, Bursa, Turkey.

Editor-in-Chief: Alexandre Rasi Aoki

Associate Editor: Alexandre Rasi Aoki

Received: 2020.11.28; Accepted: 2021.04.22.

*Correspondence: ferdaoz@uludag.edu.tr; Tel.: +90-5326098030 (F.A.)

\section{HIGHLIGHTS}

- Changes in GST enzyme activity in rat tissues exposed to fenarimol were investigated.

- GST activity was increased in liver, kidney and small intestine tissues to fenarimol exposure.

- GST activity was decreased in brain intestine tissues to fenarimol exposure.

- Fenarimol can cause a toxic effect on metabolism by causing changes in GST activity.

Abstract: The unconscious use of pesticides causes various adverse effects on non-target organisms, including humans. Enzymes that control metabolism become the target of the pesticide and the organs are damaged due to toxic effects. Glutathione s-transferase (GST, EC 2.5.1.18), an important enzyme of the detoxification mechanism and antioxidant defense system, can be affected by such toxic substances. Therefore, the effect of fenarimol on GST enzyme activity was investigated in our study. For this, $200 \mathrm{mg} / \mathrm{kg}$ fenarimol was administered intraperitoneally to male and female rats at different periods $(2,4,8,16,32,64$ and 72 hours). After application, GST enzyme activity was analysed in the liver, kidney, brain and small intestine tissues of the rats. According to our results, activation (liver, kidney, small intestine) or inhibition (brain) of the generally GST enzyme was observed in the tissues of rats exposed to fenarimol. It is thought that the increase and/or decrease in this enzyme activity may be the cause of the toxic effect of fenarimol.

Keywords: pesticide; fungicide; fenarimol; glutathione s-transferase.

\section{INTRODUCTION}

Pesticides are defined as a toxic substance or mixture of substances that kill or eliminate unwanted organisms, prevent them from multiplying and feeding [1]. Unconsciously and intensely used pesticides pose a problem for various organisms and the environment, and during their use they can accumulate in food, soil, water and air, or undergo a dangerous conversion [2-4]. Therefore, they cause adverse effects (acute 
poisoning, hormone and nervous system disorders, cancer and diabetes) on non-target organisms and humans [5-13]. Some pesticides such as dichlorvos, acetamipride, cyhalothrin, haloxyfop-p-methyl, 2,4dichlorophenoxy acetic acid, cypermethrin, imidacloprid, fenoxaprop-p-ethyl, glyphosate isopropylamine salt have been shown to inhibit the GST enzyme at millimolar level in blueberry fruits [14].

Pesticides that enter the body indirectly are removed from the body by detoxification reactions. Depending on the type of chemical change, these reactions can be divided into four groups: oxidation, reduction, hydrolysis (phase 1) and conjugation (phase 2). Pesticides are oxidized in phase 1 by cytochrome $\mathrm{P}_{450}$ monooxygenases in the liver and converted into polar compounds with short biological half-lives. In phase 2, the modified pesticides are conjugated with high polarity glucuronic acid or glutathione (GSH) in water. As a result of pesticide biotransformation, biologically activated pesticide metabolites increase their biological half-life by covalently binding to tissue macromolecules (DNA and protein). Binding of these pesticide metabolites to DNA or esterases causes a number of oncogenic or neurotoxic abnormalities to accelerate [15].

When pesticides with different classification criteria are grouped according to the target organism, fenarimol in the fungicide class is used for protection against fungal spores or fungi, especially in agriculture $[16,17]$. Members of this class with various active ingredients can affect different (single-site or multi-site) mechanisms. Those specific to the region (single region) show their effects only at one point of the metabolic pathway or on an enzyme and/or protein, depending on the needs of the target organism. Multicides, on the other hand, are effective in different metabolic pathways and target basic cellular processes that inhibit various biosynthesis in mushrooms [18]. In mammalian cells, fenarimol induces a variety of cytochrome $\mathrm{P}_{450}$ isoforms from all inducible families, including key enzymes involved in the biosynthesis and metabolism of steroids [19]. Again, as a result of studies in experimental animals, fenarimol has been shown to have teratogenic and oncogenic effects on reproduction and inhibit aromatase activity in male rats [20]. In addition, as a result of a previous study conducted by our group, it was shown that hepatic marker enzyme activities (ALP, ALT, AST and CK) and some biochemical parameters in serum were affected in fenarimol-induced rats [21].

GSTs that conjugate various hydrophobic compounds containing electrophilic centres with endogen/exogenous substances are members of the Phase-Il detoxification enzyme family. In this way, it catalyses their removal from the body and their conversion into less toxic metabolites [22,23]. GSTs that catalyse different substrates such as carcinogenic compounds, drugs, environmental pollutants, are classified according to their presence in the mitochondrial, cytosolic and microsomal parts of the cell [23]. Although it is commonly found in animals and plants, it has also been reported to be found in various organisms (flies, snails, sharks, some bacteria). The main and most important function of GST is the detoxification of reactive intermediates formed in xenobiotic metabolism. In addition, it has various physiological functions such as binding/transport of different ligands, reduction of lipid hydroperoxides, tyrosine catabolism, hormone biosynthesis and modulation of signal pathways [22,24,25].

In our study, the effect of fenarimol, which is frequently used in agriculture, on GST enzyme activity, which has an important role in the detoxification mechanism, was investigated. Accordingly, after fenarimol exposure, a significant increase in GST enzyme activity was observed in all tissues of the male and female rats, except the brain (GST inhibition was observed in the brain tissue). This study will serve as a source since there is no information about the GST enzyme activity of fenarimol in the literature.

\section{MATERIAL AND METHODS}

\section{Animals}

The study was evaluated and approved by the Bursa Uludag University Animal Use and Care Committee (Decision No. 3-06. 2003/3). The Wistar-Albino rats used in our study weighed 200-250 g and were obtained from the Experimental Animals Breeding and Research Center of Bursa Uludag University Faculty of Medicine. Rats were maintained in an environment with established standard environmental conditions (temperature $23 \pm 2{ }^{\circ} \mathrm{C}$ and $12 \mathrm{~h}$ light/dark cycle). 


\section{Animal Treatment}

A total of 48 rats were divided into 4 experimental and 2 control groups. This step was performed in the same way for each experiment period. (Control group $n=16$, experimental group $n=32$ ). While the experimental groups were injected intraperitoneally with $200 \mathrm{mg} / \mathrm{kg} \mathrm{LD} \mathrm{L}_{50}$ dose of fenarimol (Sigma-Aldrich, St. Louis, MO), the control groups were given corn oil. Rats were fasted for $24 \mathrm{~h}$ before injection. After the injection, the animals were regularly fed with food and water until the trial period was completed. Rats in the treatment and control groups were kept in special cages. The animals were euthanized by cervical dislocation at the end of each specified interval $(2,4,8,16,32,64$ and $72 \mathrm{~h}$ after injection). The brain, kidney, liver and small intestine of the rats were removed and perfused in cold $0.15 \mathrm{M} \mathrm{KCl}$. The resulting tissues were homogenized at $2000 \mathrm{rpm}$ in a T-line laboratory mixer type (model No: 136-2) homogenizer. Each homogenate was centrifuged at Dupont Instruments Sorvall (RC-5 super-fast cooled centrifuge) at $48000 \mathrm{~g}$ for 30 minutes at $4{ }^{\circ} \mathrm{C}$.

\section{Protein determination}

The protein concentration was determined by the Bradford method [26] and bovine serum albumin was used as the protein standard.

\section{Glutathione s-transferase activity}

GST enzyme activities were determined by monitoring the thioether bond formed between GST and 1chloro-2,4-dinitrobenzene (CDNB) spectrophotometrically at 340nm wavelength for 5 minutes. In the test mixture, $10 \mathrm{mM}$ potassium phosphate buffer $(\mathrm{pH}: 6.7), 5 \mathrm{mM}$ GSH prepared in potassium phosphate buffer, CDNB prepared in 99\% ethyl alcohol and cytosolic fractions of tissues were used as enzyme source. $\varepsilon$ : Extinction Coefficient was accepted as $9.6 \mathrm{mM}^{-1} \mathrm{~cm}^{-1}$ [27]. The mean of inter- and intra-assay coefficients of variation of GST activity were calculated $15 \%$ and $10 \%$ respectively.

\section{Statistical analysis}

Statistical analyses were performed using GraphPad Prism 8.4.0 (Demo Version; GraphPad, San Diego, CA) statistical package program. Independent sample t-test was applied to examine the effect of fenarimol between experimental and control groups. The significance was calculated using one-way analysis of variance (ANOVA) and Student's t-test. A value of $p<0.05, p<0.01$, and $p<0.001$ was considered statistically significant.

\section{RESULTS}

\section{Effect of fenarimol on GST activity in liver tissue}

The liver GST findings obtained as a result of the experiments are shown in Figure 1. When liver GST activity is examined in both male and female rats in all experimental periods, it is seen that GST activity is higher than the control group. GST activity is significant in all experimental periods in males and females ( $p$ $<0.001)$.
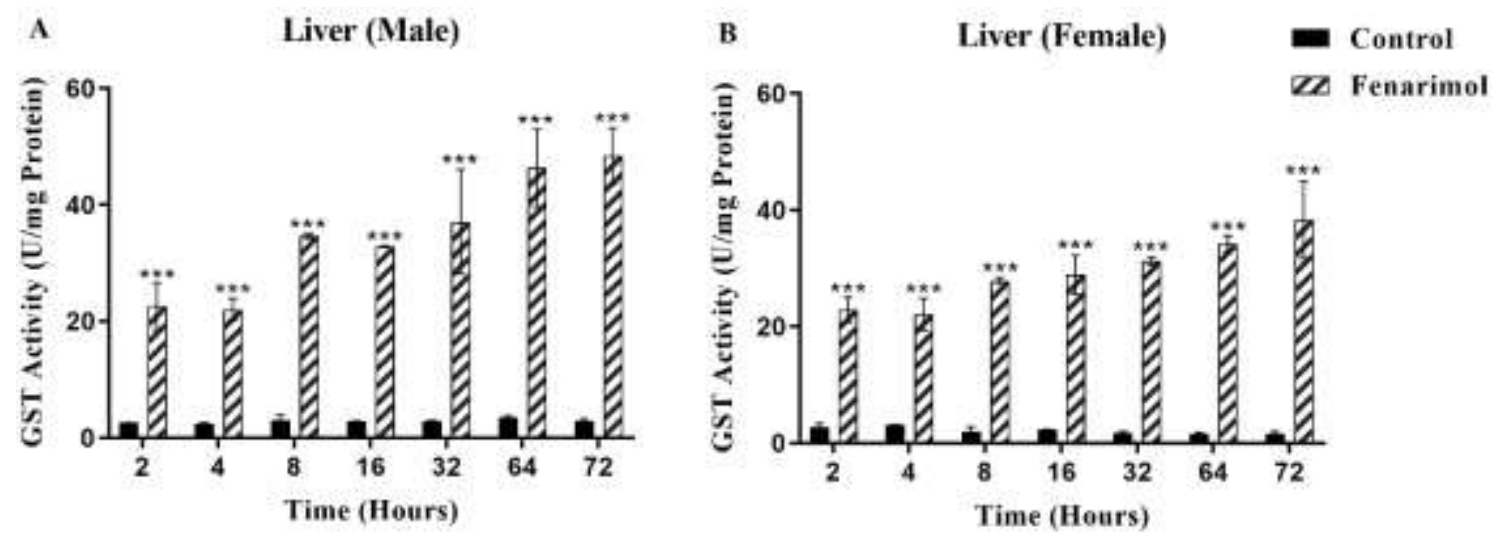

Figure 1. Effect of fenarimol on GST activity in liver tissue of rats. *Refers to statistically significant differences compared to control: * $(p<0.05) ;{ }^{* *}(p<0.01) ;{ }^{* * *}(p<0.001)$. Data are presented as mean $\pm S D(n=3)$ and analyses were performed using GraphPad program. SD, Standard Deviation; GST, Glutathione S-Transferase. 


\section{Effect of fenarimol on GST activity in kidney tissue}

The kidney GST findings obtained as a result of the experiments are shown in Figure 2. When kidney GST activity is examined in both male and female rats in all experimental periods, it is seen that GST activity is higher than the control group. GST activity is significant in all experimental periods in males and females $(p<0.001)$.
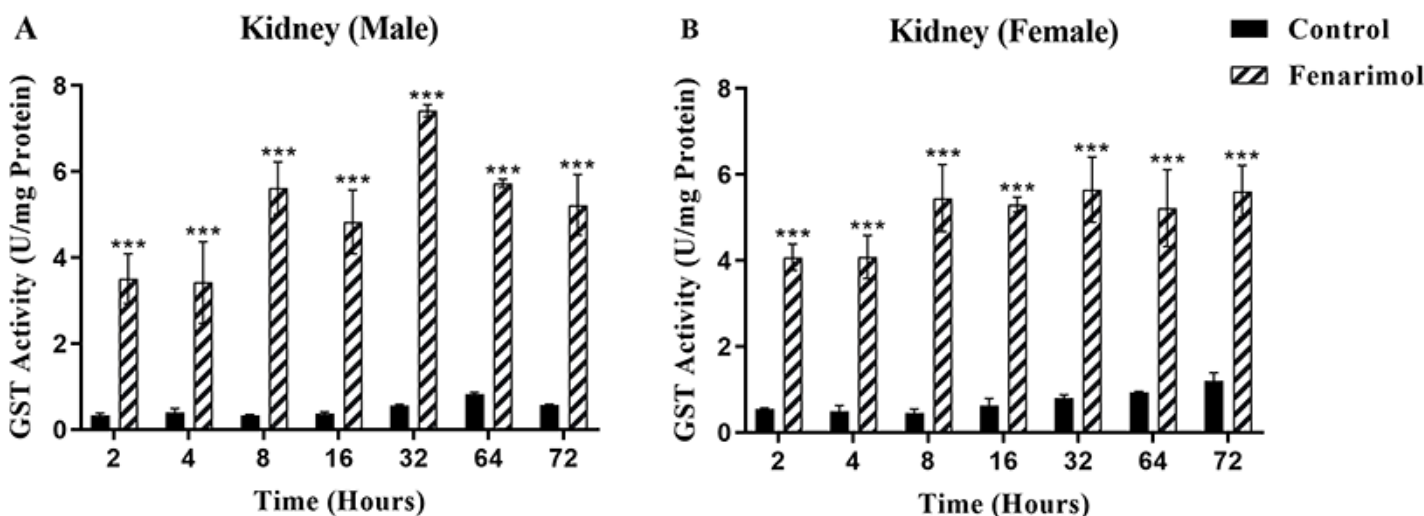

Figure 2. Effect of fenarimol on GST activity in the kidney tissue of rats. *Refers to statistically significant differences with respect to control: ${ }^{*}(p<0.05) ;{ }^{* *}(p<0.01) ;{ }^{* * *}(p<0.001)$. Data are presented as mean $\pm S D(n=3)$ and analyses were performed using GraphPad program. SD, Standard Deviation; GST, Glutathione S-Transferase.

\section{Effect of fenarimol on GST activity in brain tissue}

Brain GST findings obtained as a result of experiments are shown in Figure 3. As a result of the statistical evaluation between the control and experimental groups, GST activity was observed to decrease. Inhibition of GST activity in male rats was statistically significant at all experimental hours $(p<0.05$ and $p<0.001)$ and at 32nd and 64th $\mathrm{h}(p<0.01$ and $p<0.001)$ in female rats.
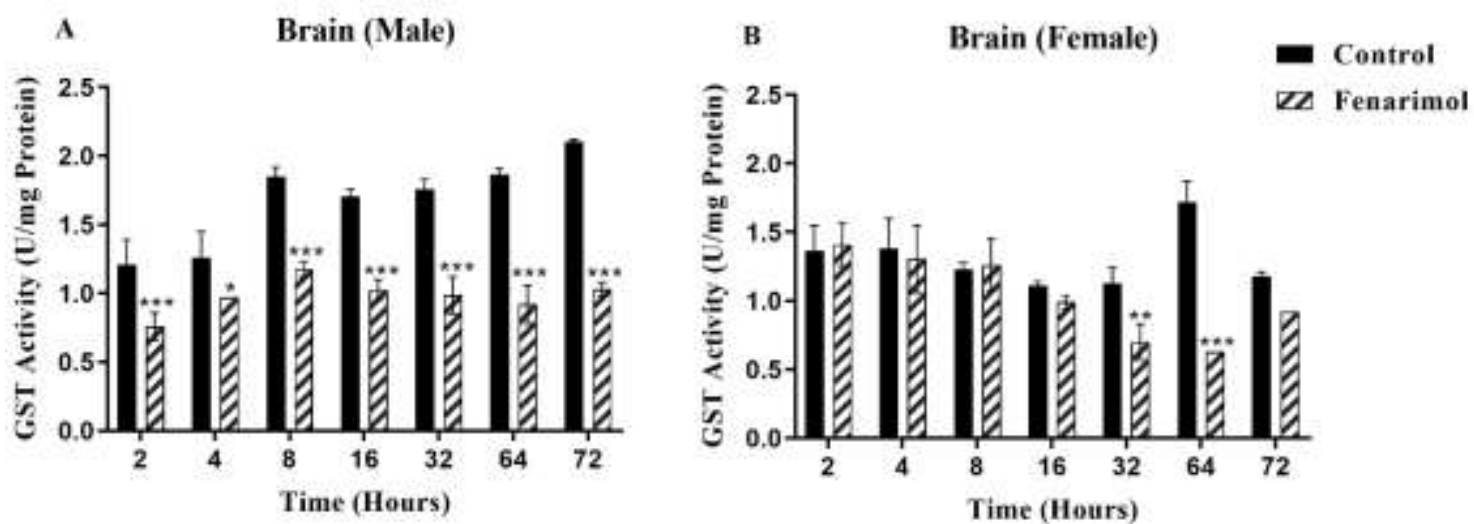

Figure 3. Effect of fenarimol on GST activity in the brain tissue of rats. *Refers to statistically significant differences with respect to control: * $(p<0.05) ;{ }^{* *}(p<0.01) ;{ }^{* * *}(p<0.001)$. Data are presented as mean $\pm S D(n=3)$ and analyses were performed using GraphPad program. SD, Standard Deviation; GST, Glutathione S-Transferase.

\section{Effect of fenarimol on GST activity in the small intestine tissue}

The small intestine GST findings obtained as a result of the experiments are shown in Figure 4. When GST activity was examined in both male and female rats in all experimental periods, it was observed that GST activity was higher than the control group. GST activity is significant in all experimental hours except for the 64th and 72th $\mathrm{h}$ in male and female rats $(p<0.001)$. 

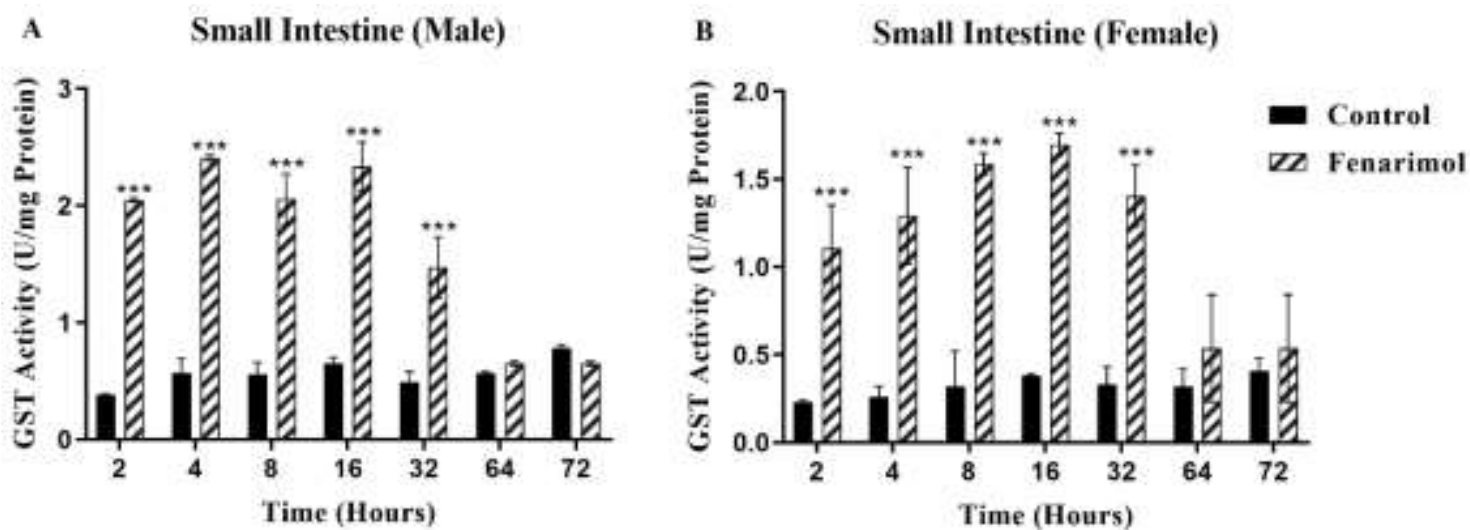

Figure 4. Effect of fenarimol on GST activity in the small intestine tissue of rats. ${ }^{*}$ Refers to statistically significant differences with respect to control: * $(p<0.05) ;{ }^{* *}(p<0.01) ;{ }^{* * *}(p<0.001)$. Data are presented as mean \pm SD $(n=3)$ and analyses were performed using GraphPad program. SD, Standard Deviation; GST, Glutathione S-Transferase.

\section{DISCUSSION}

To understand whether pesticides affect non-target organisms, enzyme activities in damaged tissues can be examined [28-32]. Although there are studies on the GST activity of pesticides in the literature [3336], there is no study on the GST activity of fenarimol in rat tissues. Therefore, it is important to know the effect of fenarimol on rats. For example, in a study [37] when they investigated the effects of lambda sihalotrin, cypermethrin, chlorpyrifos, dichlorvos, glyphosate isopropylamine pesticides on GST enzyme activity purified from turkey liver, found that these pesticides inhibit the GST enzyme in vitro. Therefore, they suggested that pesticides may pose a risk for living.

As a result of our studies, it was observed that GST activity in male and female rats treated with fenarimol increased significantly in all experimental hours $(p<001)$. Since GST plays a role in the detoxification mechanism, an increase in its activity may have been observed to get rid of the toxic effect of fenarimol. When the results are evaluated, it is seen that GST activities in the liver and kidney are higher than other tissues (Figure 1 and Figure 2). The liver acts as the main organ in metabolism, and xenobiotic, antioxidant, various toxic substances are excreted through the kidneys after they are detoxified. Therefore, it can be concluded that GST activity is higher in these tissues after fenarimol toxicity. In a previous study of our group, after applying Dichlorvos, a different type of pesticide, it was observed that GST activity increased in all tissues investigated, but the highest effect was in the liver [38]. A study with epoxyconazole, a triazole group fungicide, showed that concentrations of $8,24,40 \mathrm{mg} / \mathrm{kg}$ bw increase GST activation in liver and kidney tissues after 28 days of application to Wistar rats [39]. Carbofuran, a pesticide commonly used in [40] studies, has been shown to increase the GST enzyme activity by inducing the cytochrome $\mathrm{P}_{450}$ enzyme system in the rat liver. In another study, when the effect of in vitro methyl parathion on GST activity was examined, it was seen that GST activity was highest in the hepatic fractions of rats, mice and 10 adult people [41].

According to our results, it is seen that there is a significant decrease in GST activity in the brain tissue of both male and female rats (Figure 3). Accordingly, although the decrease in GST activity in female rats is significant at 32 and $64 \mathrm{~h}$, male rats show this result in all experimental periods. This inhibition in GST enzyme activity may have occurred due to estrogen $[42,43]$. Therefore, fenarimol, also known as an aromatase (estrogen synthase) inhibitor, can be interpreted as the cause of this decrease in the GST enzyme [19,4447]. This difference between male and female rats may be due to sex hormones affected by fenarimol. For example, chlorpyrifos, an organophosphate pesticide, is known to cause a change in hormonal balance, depending on gender [48]. In addition, atrazine has been observed to be an endocrine disrupter and inhibit testosterone production in male rats [49]. In another study, propiconazole, a different type of fungicide, has been found to be effective on endocrine distribution and reproductive parameters in male rats [50].

In conclusion, based on the experimental evidence obtained, we can suggest that GST can be useful in monitoring the effects of pesticide exposure on wildlife. However, more studies are needed to comprehensively examine the effects of fenarimol, which has been observed to cause a change in GST activity. In addition, fenarimol, which is widely used in agriculture, directly or indirectly affects the environment and living beings. Because this is critical to public health, caution should be exercised in the use of chemicals and consumers and/or manufacturers should be informed about potential hazards. 
Funding: This research was funded by Bursa Uludag University, grant number F(U)-2003/65.

Acknowledgments: We thank Hakan Tosunoğlu for their technical assistance.

Conflicts of Interest: The authors declare no conflict of interest.

\section{REFERENCES}

1. Bolognesi C. Genotoxicity of pesticides: a review of human biomonitoring studies. Mutat Res. 2003;543(3):251-72. doi:10.1016/S1383-5742(03)00015-2.

2. Faria M, Prats E, Rosas Ramírez JR, Bellot M, Bedrossiantz J, Pagano M, et al. Androgenic activation, impairment of the monoaminergic system and altered behavior in zebrafish larvae exposed to environmental concentrations of fenitrothion. Sci Total Environ. 2021;775:145671. doi:10.1016/j.scitotenv.2021.145671.

3. Fiorino E, Sehonova P, Plhalova L, Blahova J, Svobodova Z, Faggio C, et al. Effect of glyphosate on early life stages: comparison between Cyprinus carpio and Danio rerio. Environ Sci Pollut Res Int. 2018;25(9):8542-9. doi:10.1007/s11356-017-1141-5.

4. Blahova J, Cocilovo C, Plhalova L, Svobodova Z, Faggio C. Embryotoxicity of atrazine and its degradation products to early life stages of zebrafish (Danio rerio). Environ Toxicol Pharmacol. 2020;77:103370. doi:10.1016/j.etap.2020.103370.

5. Stara A, Kubec J, Zuskova E, Buric M, Faggio C, Kouba A, et al. Effects of S-metolachlor and its degradation product metolachlor OA on marbled crayfish (Procambarus virginalis). Chemospere. 2019;224:616-25. doi:10.1016/j.chemosphere.2019.02.187.

6. Stara A, Bellinvia R, Velisek J, Strouhova A, Kouba A, Faggio C, et al. Acute exposure of common yabby (Cherax destructor) to the neonicotinoid pesticide. Sci Total Environ. 2019;665:718-23. doi:10.1016/j.scitotenv.2019.02.202.

7. Pagano M, Stara A, Aliko V, Faggio C. Impact of Neonicotinoids to Aquatic Invertebrates-In Vitro Studies on Mytilus galloprovincialis: A Review. J Mar Sci Eng. 2020;8(10):801. doi:10.3390/jmse8100801.

8. Stara A, Pagano M, Capillo G, Fabrello J, Sandova M, Albano M, et al. Acute effects of neonicotinoid insecticides on Mytilus galloprovincialis: a case study with the active compound thiacloprid and the commercial formulation Calypso 480 SC. Ecotoxicol Environ Saf. 2020;203(7):110980. doi:10.1016/j.ecoenv.2020.110980.

9. Stara A, Pagano M, Capillo G, Fabrello J, Sandova M, Vazzana I, et al. Assessing the effects of neonicotinoid insecticide on the bivalve mollusc Mytilus galloprovincialis. Sci Total Environ. 2020;700:134914. doi:10.1016/j.scitotenv.2019.134914.

10. Sula E, Aliko V, Barceló D, Faggio C. Combined effects of moderate hypoxia, pesticide and PCBs upon Crucian Carp fish, Carassius carassius, from a freshwater lake-in situ ecophysiological approach. Aquat Toxicol. 2020;228:105644. doi: 10.1016/j.aquatox.2020.105644.

11. Horrigan L, Lawrence RS, Walker P. How sustainable agriculture can address the environmental and human health harms of industrial agriculture. Environ Health Perspect. 2002;110(5):445-56. doi: 10.1289/ehp.02110445.

12. Nauen R. Insecticide resistance in disease vectors of public health importance. Pest Manag Sci. 2007;63(7):62833. doi:10.1002/ps.1406.

13. Bronstein AC, Spyker DA, Cantilena LR, Rumack BH, Dart RC. 2011 Annual report of the American Association of Poison Control Centers' National Poison Data System (NPDS): 29th Annual Report. Clin Toxicol (Phila). 2012;50(10):911-1164. doi:10.3109/15563650.2012.746424.

14. Balcı N, Türkan F, Şakiroğlu H, Aygün A, Şen F. Purification and characterization of glutathione S-transferase from blueberry fruits (Vaccinium arctostaphylos L.) and investigated of some pesticide inhibition effects on enzyme activity. Heliyon. 2019;5(4),e01422. doi:10.1016/j.heliyon.2019.e01422.

15. Kurutaş EB, Kılınç M. Effects of Pesticides on Biological Systems. Arch Med Rev J. 2003;12(3):215-28.

16. Zhang H, Wang X, Zhuang S, Qian M, Jiang K, Wang X, et al. Enantioselective separation and simultaneous determination of fenarimol and nuarimol in fruits, vegetables, and soil by liquid chromatography-tandem mass spectrometry. Anal Bioanal Chem. 2012;404(6-7):1983-91. doi:10.1007/s00216-012-6325-8.

17. Oh K, Matsumoto T, Yamagami A, Hoshi T, Nakano T, Yoshizawa Y. Fenarimol, a pyrimidine-type fungicide, inhibits brassinosteroid biosynthesis. Int J Mol Sci. 2015;16(8):17273-88. doi:10.3390/ijms160817273.

18. Bolognesi C, Merlo FD. Pesticides: Human Health Effects. In: Encyclopedia of Environmental Health. Elsevier, 2019.118-32.

19. Andersen HR, Bonefeld-Jørgensen EC, Nielsen F, Jarfeldt K, Jayatissa MN, Vinggaard AM. Estrogenic effects in vitro and in vivo of the fungicide fenarimol. Toxicol Lett. 2006;163(2):142-52. doi:10.1016/j.toxlet.2005.10.004.

20. de Castro VLSS, de Mello MA, Diniz C, Morita L, Zucchi T, Poli P. Neurodevelopmental effects of perinatal fenarimol exposure on rats. Reprod Toxicol. 2007;23(1):98-105. doi:10.1016/j.reprotox.2006.09.001.

21. Ari F, Dere $E$. Effect of the sterol demethylation-inhibiting fungicide fenarimol on selected biochemical parameters in rats. Acta Vet Beo. 2010;60(1):31-8. doi:10.2298/AVB1001031A. 
22. Espinoza HM, Williams CR, Gallagher EP. Effect of cadmium on glutathione S-transferase and metallothionein gene expression in coho salmon liver, gill and olfactory tissues. Aquat Toxicol. 2012;110-111:37-44. doi:10.1016/j.aquatox.2011.12.012.

23. Ozaslan MS, Demir Y, Küfrevioğlu OI, Çiftci M. Some metals inhibit the glutathione S-transferase from Van Lake fish gills. J Biochem Mol Toxicol. 2017;31(11):e21967. doi:10.1002/jbt.21967.

24. Awasthi YC, Dao DD, Saneto RP. Interrelationship between anionic and cationic forms of glutathione Stransferases of human liver. Biochem J. 1980;191(1):1-10. doi:10.1042/bj1910001.

25. Hayes JD, Flanagan JU, Jowsey IR. Glutathione Transferases. Annu Rev Pharmacol Toxicol. 2005;45(1):51-88. doi:10.1146/annurev.pharmtox.45.120403.095857.

26. Bradford MM. A rapid and sensitive method for the quantitation of microgram quantities of protein utilizing the principle of protein-dye binding. Anal Biochem. 1976;72(1-2):248-54. doi:10.1006/abio.1976.9999.

27. Habig WH, Pabst MJ, Jakoby WB. Glutathione $S$ transferases. The first enzymatic step in mercapturic acid formation. J Biol Chem. 1974;249(22):7130-9.

28. Lushchak VI, Matviishyn TM, Husak VV, Storey JM, Storey KB. Pesticide toxicity: A mechanistic approach. Exp Clin Sci J. 2018;17:1101-36. doi:10.17179/excli2018-1710.

29. Gharaei A, Karimi M, Harijani JM, Miri M, Faggio C. Population growth of Brachionus calyciflorus affected by deltamethrin and imidacloprid insecticides. Iran J Fish Sci. 2020;19(2):588-6.

30. Petrovici A, Strungaru SA, Nicoara M, Robea MA, Solcan C, Faggio C. Toxicity of Deltamethrin to Zebrafish Gonads Revealed by Cellular Biomarkers. J Mar Sci Eng. 2020;8(2):73. doi:10.3390/jmse8020073.

31. Plhalova L, Blahova J, Divisova L, Enevova V, Casuscelli Di Tocco F, Faggio C, et al. The effects of subchronic exposure to NeemAzal T/S on zebrafish (Danio rerio). Chem Ecol. 2018;34(3):199-210. doi:10.1080/02757540.2017.1420176.

32. Chromcova L, Blahova J, Zivna D, Plhalova L, Casuscelli Di Tocco F, Divisova L, et al. NeemAzal T/S - toxicity to early-life stages of common carp (Cyprinus carpio L.). Vet Med. 2015;60:(1):23-30. doi:10.17221/7922-VETMED.

33. Ari F, Dere E. Glutathione S-transferase activity in rats exposed to methyl parathion. Chem Ecol. 2008;24(3):2139. doi:10.1080/02757540802119889.

34. Ari F, Dere E, Tosunoglu H, Alioğlu I. The effects of fenarimol and methyl parathion on glucose 6-phosphate dehydrogenase enzyme activity in rats. Turk J Agric Res. 2017;4(3):275-80. doi:10.19159/tutad.310371.

35. Pavlidi N, Vontas J, Van Leeuwen T. The role of glutathione S-transferases (GSTs) in insecticide resistance in crop pests and disease vectors. Cur Opin Insect Sci. 2018;27:97-102. doi:10.1016/j.cois.2018.04.007.

36. Wang $\mathrm{H}$, Zhang $\mathrm{X}$, Wang $\mathrm{L}$, Zhu B, Guo W, Liu W, et al. Biochemical responses and DNA damage induced by herbicide QYR301 in earthworm (Eisenia fetida). Chemosphere. 2020;244:125512. doi:10.1016/j.chemosphere.2019.125512.

37. Güller P, Akkemik E, Kör S, Çitçi M. Investigation of Some Pesticides' Effects on Activities of Glutathione Reductase and Glutathione S-Transferase Purified from Turkey Liver under in Vitro Conditions. J Inst Sci Technol. 2018;8(3):211-7. doi:10.21597/jist.458632.

38. Ozdikicioglu F, Dere E, Tosunoglu H. The Effect of Dichlorvos on Glutathione S-Transferase Activity in Some Tissues of Rats. J Appl Biol Sci. 2008;2(1):35-8.

39. Hamdi $H$, Othmène $Y B$, Ammar $O$, Klifi $A$, Hallara $E$, Ghali FB, et al. Oxidative stress, genotoxicity, biochemical and histopathological modifications induced by epoxiconazole in liver and kidney of Wistar rats. Environ Sci Pollut Res. 2019;26(17):17535-47. doi:10.1007/s11356-019-05022-3.

40. Kaur M, Sandhir R. Comparative effects of acute and chronic carbofuran exposure on oxidative stress and drugmetabolizing enzymes in liver. Drug Chem Toxicol. 2006;29(4):415-21. doi:10.1080/01480540600837969.

41. Bammler TK, Abel E, Eaton DL. Metabolism of methyl parathion by glutathione S-transferases in vitro. Chem Biol Interact. 2001;133(1):231-3.

42. Ansell PJ, Espinosa-Nicholas C, Curran EM, Judy BM, Philips BJ, Hannink M, et al. In Vitro and in Vivo Regulation of Antioxidant Response Element-Dependent Gene Expression by Estrogens. Endocrinol. 2004;145(1):311-7. doi:10.1210/en.2003-0817.

43. Fucic A, Gamulin M, Ferencic Z, Katic J, Krayer Von Krauss M, Bartonova A, et al. Environmental exposure to xenoestrogens and oestrogen related cancers: Reproductive system, breast, lung, kidney, pancreas, and brain. Environ Heal A Glob Access Sci Source. 2012;11(1):1-9. doi:10.1186/1476-069X-11-S1-S8.

44. Hirsch KS, Jones CD, Lindstrom TD, Stamm NB, Sutton GP, Taylor HM, et al. Discovery and development of a novel class of nonsteroidal aromatase inhibitors. Steroids. 1987;50(1-3):201-17. doi:10.1016/0039128X(83)90072-7.

45. Vinggaard AM, Breinholt $\mathrm{V}$, Larsen JC. Screening of selected pesticides for oestrogen receptor activation in vitro. Food Addit Contam. 1999;16(12):533-42. doi:10.1080/026520399283678. 
46. Hinfray N, Porcher JM, Brion F. Inhibition of rainbow trout (Oncorhynchus mykiss) P450 aromatase activities in brain and ovarian microsomes by various environmental substances. Comp Biochem Physiol C: Toxicol Pharmacol. 2006;144(3):252-62. doi:10.1016/j.cbpc.2006.09.002.

47. Laville N, Balaguer P, Brion F, Hinfray N, Casellas C, Porcher JM, et al. Modulation of aromatase activity and mRNA by various selected pesticides in the human choriocarcinoma JEG-3 cell line. Toxicol. 2006;228(1):98-108. doi:10.1016/j.tox.2006.08.021.

48. Ventura C, Nieto M, Bourguignon N, Lux-Lantos V, Rodriguez H, Cao G, et al. Pesticide chlorpyrifos acts as an endocrine disruptor in adult rats causing changes in mammary gland and hormonal balance. J Steroid Biochem Mol Biol. 2016;156:1-9. doi:10.1016/j.jsbmb.2015.10.010.

49. Friedmann AS. Atrazine inhibition of testosterone production in rat males following peripubertal exposure. Reprod Toxicol. 2002;16(3):275-9. doi:10.1016/S0890-6238(02)00019-9.

50. Costa NO, Vieira ML, Sgarioni V, Pereira MRF, Montagnini BG, Mesquita SFP, et al. Evaluation of the reproductive toxicity of fungicide propiconazole in male rats. Toxicol. 2015;335:55-61. doi:10.1016/j.tox.2015.06.011.

(C) 2021 by the authors. Submitted for possible open access publication under the terms and conditions of the Creative Commons Attribution (CC BY NC) license (https://creativecommons.org/licenses/by-nc/4.0/). 